\title{
The Influence of Discipline and Motivation on Employee Performance in PT Panca Usaha Lestari in Jakarta
}

\author{
Devi Fitria Wilandari \\ Universitas Pamulang \\ E-mail: dosen02529@unpam.ac.id
}

\begin{abstract}
Enforcing discipline is important for the company, because discipline contains rules that employees must obey. This study aims to determine the effect of discipline and motivation on employee performance at PT. Panca Usaha Sustainable in Jakarta. The method used was explanatory research with a sample of 62 respondents. The analysis technique uses statistical analysis with regression testing, correlation, determination and hypothesis testing. The results of this study have a significant effect on discipline employee performance by $47.1 \%$, hypothesis testing obtained significance $0,000<0.05$. Motivation has a significant effect on employee performance by $38.7 \%$, hypothesis testing obtained significance 0,000 $<0.05$. Discipline and simultaneous significant effect on employee performance by $56.9 \%$, hypothesis testing obtained significance of $0,000<0.05$.
\end{abstract}

Keywords: Discipline; motivation; employee performance.

\section{INTRODUCTION}

The role of human resources in the company is very important, considering that employees as executors of achieving the goals expected by the company (Hasibuan, 2018; Sunyoto, 2012; Yani, 2011). Therefore it is important that company management always provides direction and motivation and also ensures that all regulations in the company can be adhered to properly by all employees at management level until employees are at a low level (Chairil, 2017; Ningsi, Alhabsji, \& Utami, 2016; Tahir, 2016).

Work discipline that is not going well will have an impact on the progress of the organization. Without good discipline in employees, it is difficult for organizations to achieve optimal results. Undisciplined (Indisciplinary) action will have an impact on the growth of the company's organization. Discipline is also said as a means to train and educate people on rules so that there is compliance and so that it can run in a thin and orderly manner in the organization. Company regulations are made of course aimed at being able to be obeyed by employees both from obedience of employees in keeping work time, obedience in complying with all the rules in the company, compliance with employee behavior in carrying out their duties and obligations, employee obedience in upholding legal norms and other rules.

Enforcing discipline is important for the company, because it contains regulations that employees must obey (Dul et al., 2012; Pacione, 2015; Saleh, 2014). With discipline is expected to make work as efficient as possible. Work discipline can be seen as something of great benefit, both for the benefit of the organization and for the employees. For organizations the existence of work discipline will guarantee the maintenance of order and the smooth implementation of tasks, so that optimal results are obtained (Gomes, 2003; Karpoff, 2012; Prihantoro, 2012; 


\section{Jurnal Administrare: Jurnal Pemikiran Ilmiah dan Pendidikan Administrasi Perkantoran Vol. 7, No. 1, January - June 2020, Pages 49-56}

Sedarmayanti, 2017). Whereas employees will get a pleasant working atmosphere so that it will increase the morale in carrying out their work. Employees must also have a high sense of responsibility to show our discipline in work, such as doing the assigned tasks and completing them on time. Disciplined workers not only always accept assigned tasks, completing tasks perfectly are also a form of responsibility for work (Azwar, 2015; Busro, 2019; Sinambela, 2016; Susanto, 2019)

Motivation will arise if people already feel fulfilled all their needs, therefore if their needs are not met it will lead to problems that lead to several cases that often occur in companies such as labor strikes, demands for wage increases and so forth, this is a sign that there is dissatisfaction felt by employees of the company. The role of motivation is to intensify these desires and desires, therefore it can be concluded that efforts to increase one's morale will always be related to motivating efforts so that to carry out good motivation needs to know human needs (Astuti, Saleh, Baharuddin, \& Salam, 2016 ; Fatonah, Purnomo, \& Salam, 2019). With the influence of motivation, work discipline and job satisfaction will make employees more advanced (Dapu, 2015; Marwanto \& Nugroho, 2014; Sutrisno, Fathoni, \& Minarsih, 2016). Performance can be achieved by companies by building all elements within the company to be able to work effectively. According to (Mangkunegara, 2003) the notion of performance is the work of quality and quantity achieved by an employee in carrying out their duties in accordance with the responsibilities given to him.

\section{METHOD}

The type of research used is associative, where the aim is to find out the connection between. The population in this study amounted to 62 employees of PT. Panca Usaha Sustainable in Jakarta The sampling technique in this study is saturated sampling, where all members of the population are sampled. Thus the sample in this study amounted to 62 respondents. In analyzing the data used the instrument test, classical assumption test, regression, coefficient of determination and hypothesis testing.

\section{RESULT AND DISCUSSION}

Important factors that influence employee performance are work motivation, work discipline and job satisfaction so that goals can be achieved. The influence of motivation from superiors and companies is very important in order to improve employee welfare and discipline that grows from oneself is very important in order to arise a sense of responsibility in work. There is a sense of reciprocity in accordance with what has been done, employees will feel satisfaction. With the influence of motivation, work discipline and job satisfaction will make employees more advanced.

\section{Descriptive Analysis}

In this test used to determine the highest minimum and maximum scores, ratting scores and standard deviations of each variable. The results are as follows: 


\section{Table 1}

\section{Statistical Descriptive Analysis Results}

Descriptive Statistics

\begin{tabular}{lr|r|r|r|r}
\hline & N & \multicolumn{1}{|c|}{ Minimum } & Maximum & \multicolumn{1}{c|}{ Mean } & \multicolumn{1}{c}{ Std. Deviation } \\
\hline Work Discipline (X1) & 62 & 31 & 48 & 38.19 & 4.288 \\
\hline Motivation (X2) & 62 & 31 & 48 & 38.26 & 3.887 \\
\hline $\begin{array}{l}\text { Employee Performance } \\
\text { (Y) }\end{array}$ & 62 & 33 & 46 & 39.27 & 3.636 \\
\hline Valid N (listwise) & 62 & & & & \\
\hline
\end{tabular}

Discipline obtained a minimum variance of 31 and a maximum variance of 48 with a ratting score of 38.19 with a standard deviation of 4.288 . Motivation obtained a minimum variance of 31 and a maximum variance of 48 with a ratting score of 38.26 with a standard deviation of 3.887. Employee performance obtained a minimum variance of 33 and a maximum variance of 46 with a ratting score of 39.27 with a standard deviation of 3.636.

\section{Multiple Regression Analysis}

This regression test is intended to determine changes in the dependent variable if the independent variable changes. The test results are as follows:

Table 2

Multiple Regression Testing Results

Coefficients $^{\text {a }}$

\begin{tabular}{|c|c|c|c|c|c|c|}
\hline \multirow{2}{*}{\multicolumn{2}{|c|}{ Model }} & \multicolumn{2}{|c|}{$\begin{array}{l}\text { Unstandardized } \\
\text { Coefficients }\end{array}$} & \multirow{2}{*}{$\begin{array}{c}\text { Standardized } \\
\text { Coefficients } \\
\text { Beta }\end{array}$} & \multirow[b]{2}{*}{$\mathrm{t}$} & \multirow[b]{2}{*}{ Sig. } \\
\hline & & $\mathrm{B}$ & Std. Error & & & \\
\hline 1 & (Constant) & 10,081 & 3,373 & & 2,989 & .004 \\
\hline & Work Discipline (X1) & .422 & .085 & 498 & 4,987 & .000 \\
\hline & Motivation (X2) & 342 & .93 & 366 & 3,663 & .001 \\
\hline
\end{tabular}

a. Dependent Variable: Employee Performance (Y)

Based on the test results in the above table, the regression equation $\mathrm{Y}=10.081+$ $0.422 \mathrm{X} 1+0.342 \mathrm{X} 2$ is obtained. A constant of 10,081 means that if there is no discipline and motivation, there is an employee performance value of 10,081 points. Discipline regression coefficient of 0.422 , this number is positive, which means that every time there is an increase in discipline of 0.422 , the employee's performance will also increase as big as 0.422 points. The regression coefficient of motivation is 0.342 , this number is positive, meaning that every time there is an increase in motivation by 0.342 , the employee's performance will also increase by 0.342 points. 
52 Jurnal Administrare: Jurnal Pemikiran Ilmiah dan Pendidikan Administrasi Perkantoran
Vol. 7, No. 1, January - June 2020, Pages $49-56$

\section{Correlation Coefficient Analysis}

Correlation coefficient analysis is intended to determine the degree of relationship strength of the independent variables on the dependent variable either partially or simultaneously. The test results are as follows:

Table 3.

Discipline Correlation Coefficient Testing Results on Employee Performance. Correlations $^{\text {b }}$

\begin{tabular}{llr|r}
\hline & & Disiplin Kerja (X1) & Kinerja Karyawan (Y) \\
\hline Work Discipline (X1) & Pearson Correlation & 1 & $.686^{* *}$ \\
\cline { 2 - 4 } & Sig. (2-tailed) & & .000 \\
\hline Employee & Pearson Correlation & $.686^{* *}$ & 1 \\
\cline { 2 - 4 } Performance (Y) & Sig. (2-tailed) & .000 & \\
\hline
\end{tabular}

**. Correlation is significant at the 0.01 level (2-tailed).

b. Listwise $\mathrm{N}=62$

Based on the test results obtained a correlation value of 0.686 means that discipline has a strong relationship with employee performance.

\section{Table 4}

Test Results Correlation Coefficient Motivation on Employee Performance.

\begin{tabular}{llr|r}
\multicolumn{2}{c}{ Correlations $^{\mathbf{b}}$} & \multicolumn{1}{c}{$\begin{array}{c}\text { Motivation } \\
(\mathrm{X} 2)\end{array}$} & \multicolumn{1}{c}{$\begin{array}{c}\text { Employee } \\
\text { Performance (Y) }\end{array}$} \\
\hline Motivation (X2) & Pearson Correlation & 1 & $.622^{* *}$ \\
\cline { 2 - 4 } & Sig. (2-tailed) & & .000 \\
\hline $\begin{array}{l}\text { Employee Performance } \\
\text { (Y) }\end{array}$ & Pearson Correlation & $.622^{* *}$ & 1 \\
\cline { 2 - 4 } & Sig. (2-tailed) & .000 & \\
\hline
\end{tabular}

**. Correlation is significant at the 0.01 level (2-tailed).

b. Listwise $\mathrm{N}=62$

Based on the test results obtained a correlation value of 0.622 means that motivation has a strong relationship with employee performance.

\section{Table 5}

The Results of Disciplinary Correlation Coefficient Testing and Simultaneous Motivation on Employee Performance.

\begin{tabular}{|c|c|c|c|c|}
\hline \multicolumn{5}{|c|}{ Summary Model } \\
\hline Model & $\mathrm{R}$ & R Square & Adjusted R Square & $\begin{array}{l}\text { Std. Error of the } \\
\text { Estimate }\end{array}$ \\
\hline 1 & $.754^{\mathrm{a}}$ & .569 & .554 & 2,427 \\
\hline
\end{tabular}

a. Predictors: (Constant), Motivation (X2), Work Discipline (X1) 
Based on the test results obtained by the correlation value of 0.754 means that discipline and motivation simultaneously have a strong relationship to employee performance.

\section{Analysis of the Coefficient of Determination}

Analysis of the coefficient of determination is intended to determine the percentage of influence of the independent variable on the dependent variable either partially or simultaneously. The test results are as follows:

Table 6

Discipline Determination Coefficient Testing Results on Employee Performance. Summary Model

\begin{tabular}{ll|r|r|r}
\hline Model & R & R Square & Adjusted R Square & \multicolumn{2}{c}{$\begin{array}{c}\text { Std. Error of the } \\
\text { Estimate }\end{array}$} \\
\hline 1 & $.686^{\mathrm{a}}$ & .471 & .462 & 2,666 \\
\hline
\end{tabular}

a. Predictors: (Constant), Work Discipline (X1)

Based on the test results obtained a determination value of 0.471 means that discipline has an influence contribution of $47.1 \%$ on employee performance.

Table 7

Motivation Determination Coefficient Testing Results on Employee Performance. Summary Model

\begin{tabular}{lrr|r|rr}
\hline Model & & & & \multicolumn{2}{c}{$\begin{array}{c}\text { Std. Error of the } \\
\text { Estimate }\end{array}$} \\
\hline 1 & & R Square & Adjusted R Square & .377 & 2,869 \\
\hline
\end{tabular}

a. Predictors: (Constant), Motivation (X2)

Based on the test results obtained a determination value of 0.387 means that motivation has an influence contribution of $38.7 \%$ on employee performance.

Table 8

Determination Coefficient Test Results Discipline and Motivation on Employee Performance.

Summary Model

\begin{tabular}{|c|c|c|c|c|}
\hline Model & $\mathrm{R}$ & R Square & $\begin{array}{l}\text { Adjusted R } \\
\text { Square }\end{array}$ & $\begin{array}{l}\text { Std. Error of the } \\
\text { Estimate }\end{array}$ \\
\hline 1 & $.754^{\mathrm{a}}$ & .569 & .554 & 2,427 \\
\hline
\end{tabular}

a. Predictors: (Constant), Motivation (X2), Work Discipline (X1)

Based on the test results obtained a determination value of 0.569 means that discipline and motivation simultaneously have an influence contribution of $56.9 \%$ on employee performance, while the remaining $43.1 \%$ is influenced by other factors. 


\section{Jurnal Administrare: Jurnal Pemikiran Ilmiah dan Pendidikan Administrasi Perkantoran Vol. 7, No. 1, January - June 2020, Pages 49-56}

\section{Hypothesis testing}

Hypothesis testing with $\mathrm{t}$ test is used to find out which partial hypotheses are accepted.

\section{Table 9}

Disciplinary Hypothesis Test Results on Employee Performance.

\section{Coefficients $^{\text {a }}$}

\begin{tabular}{|c|c|c|c|c|c|c|}
\hline \multirow{2}{*}{\multicolumn{2}{|c|}{ Model }} & \multicolumn{2}{|c|}{$\begin{array}{l}\text { Unstandardized } \\
\text { Coefficients }\end{array}$} & \multirow{2}{*}{$\begin{array}{l}\text { Standardized } \\
\text { Coefficients } \\
\text { Beta }\end{array}$} & \multirow[b]{2}{*}{$\mathrm{t}$} & \multirow[b]{2}{*}{ Sig. } \\
\hline & & $\mathrm{B}$ & Std. Error & & & \\
\hline \multirow[t]{2}{*}{1} & (Constant) & 17.049 & 3.059 & & 5.573 & .000 \\
\hline & Disiplin Kerja (X1) & .582 & .080 & .686 & 7.310 & .000 \\
\hline
\end{tabular}

a. Dependent Variable: Employee Performance (Y)

Based on the test results on the table above, the value of $t$ count $>t$ table or $(7.310>2,000)$ is obtained, thus the first hypothesis proposed that there is a significant influence between discipline on employee performance is accepted.

Table 10

Motivation Hypothesis Test Results on Employee Performance.

\begin{tabular}{|c|c|c|c|c|c|c|}
\hline \multirow[b]{3}{*}{ Model } & & \multicolumn{2}{|c|}{ Coefficients $^{\mathrm{a}}$} & \multirow[b]{2}{*}{$\begin{array}{l}\text { Standardized } \\
\text { Coefficients }\end{array}$} & \multirow[b]{3}{*}{$\mathrm{t}$} & \multirow[b]{3}{*}{ Sig. } \\
\hline & & \multicolumn{2}{|c|}{$\begin{array}{c}\text { Unstandardized } \\
\text { Coefficients }\end{array}$} & & & \\
\hline & & B & Std. Error & Beta & & \\
\hline \multirow[t]{2}{*}{1} & (Constant) & 17.005 & 3.634 & & 4.680 & .000 \\
\hline & Motivasi (X2) & .582 & .095 & .622 & 6.160 & .000 \\
\hline
\end{tabular}

a. Dependent Variable: Employee Performance (Y)

Based on the test results in the above table, the value of $t_{\text {count }}>t$ table or $(6.160>2,000)$ is obtained, thus the second hypothesis proposed that there is a significant influence between motivation on employee performance is accepted.

Hypothesis testing with the F test is used to find out which simultaneous hypotheses are accepted.

Table 11.

Disciplinary Hypothesis Test Results and Motivation Against Employee Performance.

ANOVA ${ }^{a}$

\begin{tabular}{ll|r|r|r|r|c}
\hline Model & Sum of Squares & \multicolumn{1}{c}{ df } & Mean Square & \multicolumn{1}{c}{ F } & \multicolumn{1}{c}{ Sig. } \\
\hline \multirow{2}{*}{1} & Regression & 458,839 & 2 & 229,420 & 38,952 & $.000^{\mathrm{b}}$ \\
\cline { 2 - 7 } & Residual & 347,499 & 59 & 5890 & & \\
\cline { 2 - 7 } & Total & 806,339 & 61 & & & \\
\hline
\end{tabular}

a. Dependent Variable: Employee Performance (Y)

b. Predictors: (Constant), Motivation (X2), Work Discipline (X1) 
Based on the test results in the table above, obtained the value of $\mathrm{F}_{\text {Count }}>\mathrm{F}$ table or $(38,952>2,760)$, thus the third hypothesis proposed that there is a significant influence between discipline and motivation on employee performance is accepted.

\section{CONCLUSION}

Based on the results of research conducted, it was found that discipline had a significant effect on employee performance with an influence contribution of $47.1 \%$. Hypothesis testing obtained values of $t$ count $>t$ table or $(7.310>2,000)$. Motivation has a significant effect on employee performance with an influence contribution of $38.7 \%$. Test hypothesis obtained by value $\mathrm{t}_{\text {count }}>\mathrm{t}$ table or $(6,160>2,000)$. Discipline and motivation have a significant effect on employee performance with a contribution of $56.9 \%$ while the remaining $43.1 \%$ is influenced by other factors. Hypothesis testing obtained the value of $\mathrm{F}_{\text {count }}>\mathrm{F}_{\text {table }}$ or (38.952> 2.760).

\section{REFERENCES}

Astuti, A., Saleh, S., Baharuddin, A., \& Salam, R. (2016). Studi Motivasi Kerja Pegawai pada PT. Bank Sulselbar Cabang Utama Makassar. JURNAL ILMU ADMINISTRASI PERKANTORAN (JIAP), 79-88.

Azwar. (2015). Pengaruh Gaya Kepemimpinan, Komunikasi, Dan Disiplin Kerja Terhadap Kinerja Karyawan. Jurnal Ilmu Dan Riset Manajemen.

Busro, M. D. (2019). Teori-teori Manajemen Sumber Daya Manusia. In Teori-teori Manajemen Sumber Daya Manusia.

Chairil, A. (2017). Pengaruh Fungsi Kepemimpinan terhadap Motivasi Kerja Pegawai pada kantor Dinas Pendidikan Kabupaten Sinjai. Jurnal Office, 2(1), 1-8.

Dapu. (2015). the Influence of Work Discipline, Leadership, and Motivation on Employee Performance At Pt. Trakindo Utama Manado. Jurnal Riset Ekonomi, Manajemen, Bisnis Dan Akuntansi.

Dul, J., Bruder, R., Buckle, P., Carayon, P., Falzon, P., Marras, W. S., ... van der Doelen, B. (2012). A strategy for human factors/ergonomics: Developing the discipline and profession. Ergonomics. https://doi.org/10.1080/00140139.2012.661087

Fatonah, A. D. I., Purnomo, A., \& Salam, R. (2019). Efektivitas Pemberian Reward dalam Pembelajaran IPS untuk Meningkatkan Motivasi Belajar Kelas VII Mts. Negeri Margadana Kota Tegal. SOSIOLIUM: Jurnal Pembelajaran IPS, 1(2), 169-173.

Gomes, F. C. (2003). Manajemen sumber daya manusia. Yogyakarta: Andi.

Hasibuan. (2018). Manajemen Sumber Daya Manusia. In Manajemen Sumber Daya Manusia.

Karpoff, J. M. (2012). Does Reputation Work to Discipline Corporate misconduct? In The Oxford Handbook of Corporate Reputation. https://doi.org/10.1093/oxfordhb/9780199596706.013.0018

Mangkunegara, A. A. A. P. (2003). Manajemen Sumber Daya Manusia Perusahaan. In Remaja 

56 Jurnal Administrare: Jurnal Pemikiran Ilmiah dan Pendidikan Administrasi Perkantoran
Vol. 7, No. 1, January - June 2020, Pages $49^{-56}$

Rosdakarya. https://doi.org/10.1038/cddis.2011.1

Marwanto, T. B., \& Nugroho, R. (2014). Pengaruh Kompensasi Dan Lingkungan Kerja Terhadap Motivasi Dan Disiplin Kerja Prajurit Di Satuan Kerja KRI X Armada RI Kawasan Timur. Jurnal Ilmu Ekonomi \& Manajemen.

Ningsi, C. A., Alhabsji, T., \& Utami, H. N. (2016). Pengaruh Pelatihan Dan Promosi Terhadap Motivasi Dan Kinerja Karyawan (Studi Pada Karyawan Pt. pln (Persero) Area Kendari). Jurnal Ilmiah Ilmu Administrasi Publik: Jurnal Pemikiran Dan Penelitian Administrasi Publik, 5(2), 131-143.

Pacione, C. (2015). The discipline of innovation. Proceedings of the Human Factors and Ergonomics Society. https://doi.org/10.1177/1541931215591062

Prihantoro, A. (2012). Peningkatan Kinerja Sumber Daya Manusia Melalui Motivasi, Disiplin, Lingkungan Kerja Dan komitmen. Jurnal Studi Manajemen Organisasi.

Saleh, S. (2014). Penegakan Disiplin (Suatu Upaya Peningkatan Kinerja Pegawai). Jurnal Ad'ministrare, 1(1), 8-19.

Sanjaya, W. (2008). Kurikulum Dan Pembelajaran (Teori \& Praktek KTSP).

Sanjaya, W. (2010). Strategi Pembelajaran Berorientasi Standar Proses Pendidikan. System.

Sanjaya, W. (2015). Perencanaan dan Desain Sistem Pembelajaran. Kencana,Prenadamedia Group.

Sedarmayanti. (2017). Manajemen Sumber Daya Manusia. In Manajemen Sumber Daya Manusia.

Sinambela, L. P. (Prof. D. (2016). Manajemen Sumber Daya Manusia. In PT.Bumi Aksara.

Sunyoto, D. (2012). Manajemen Sumber Daya Manusia. Yogyakarta: CAPS (Center Of Academic Publishing Service).

Susanto, N. (2019). Pengaruh Motivasi Kerja, Kepuasan Kerja, dan Disiplin Kerja Terhadap Kinerja Karyawan Pada Divisi Penjualan PT Rembaka. Agora.

Sutrisno, Fathoni, A., \& Minarsih, M. M. (2016). Pengaruh Motivasi Dan Disiplin Kerja Terhadap Kinerja Pegawai Di Kantor Satuan Polisi Pamong Praja Kota Semarang. Journal Of Management.

Tahir, N. (2016). Motivasi Kerja Pegawai dalam Pelayanan Publik di Sekretariat Pemerintah Daerah Kabupaten Takalar. Jurnal Ad'ministrare: Jurnal Pemikiran Ilmiah Dan Pendidikan Administrasi Perkantoran, 3(2), 1-10.

Uno, H. H. B. (2010). Model pembelajaran: menciptakan proses belajar mengajar yang kreatif dan efektif. In Jakarta: Bumi Aksara. https://doi.org/10.1038/cddis.2011.1

Yani, M. (2011). Manajemen Sumber Daya Manusia. Jurnal Perspektif. https://doi.org/ISSN $1411-8637$ 